\title{
A study of challenges, issues and motives of self-initiated expatriates in Delhi National Capital Region
}

\section{Parul Saxena*}

Department of HR and OB, School of Business Studies, Sharda University, India

Email: Parul.saxena@sharda.ac.in

*Corresponding author

\section{Bahrullah Safi}

Sharda University,

Greater Noida, India

Email: bahrullah44@yahoo.in

\begin{abstract}
As the labour market becomes more competitive, the companies are facing a serious talent crunch, and are continuously exploring ways to bridge the gap. The self-initiated expatriates (SIEs) provide a ready to use talent pool which the companies can harness to their advantage. And for this purpose, a better understanding of SIEs is vital to improve and design human resource policies. This exploratory study based on the primary data examines the purpose and motives that prompts these SIEs to move to a different country to pursue their career. It also throws light onto the various issues and concerns faced by them. The data was collected through semi-structured interviews of the SIEs working in Delhi NCR. The findings reveal that self-initiated expatriates consider India as one of the favourable destinations to work, and the SIEs have settled well in general.
\end{abstract}

Keywords: self-initiated expatriates; SIEs; motives; challenges.

Reference to this paper should be made as follows: Saxena, P. and Safi, B. (2022) 'A study of challenges, issues and motives of self-initiated expatriates in Delhi National Capital Region', Int. J. Cultural Management, Vol. 1, No. 1, pp.40-57.

Biographical notes: Parul Saxena is an accomplished professional and academician, and brings in 18 years of total experience out of which eight years working for corporates based out of the USA/India, and over ten years into academics. Presently working as Head of HR \& OB Department, School of Business Studies, and holding an additional charge of Vice-Chairperson Career Counselling and Development Centre, Sharda University. She has presented several research papers at national and international conferences. As a trainer, she has conducted and organised FDPs and MDPs for national and international clientele. She is a certified assessor for person profile analysis (PPA), and TEIQ from Thomson International, UK. 
Bahrullah Safi is a soft skills trainer, educational consultant, radio broadcaster and a research scholar from the Sharda University, Greater Noida, India. He has been actively engaged in teaching and writing for the last few years. He has been an active anchor in many national and international events and he has also participated in several conferences. $\mathrm{He}$ is an author of English language program named, English for everyone, and he has also published and presented research papers and articles jointly. He has been the recipient of several awards and appreciation certificates.

This paper is a revised and expanded version of a paper entitled 'A study of challenges, issues and motives of self-initiated expatriates of Delhi NCR' presented at 3rd International Conference on Evidence Based Management (ICEBM2019) organized by Department of Management, BITS Pilani Campus, India, 1-2 February 2019.

\section{Introduction}

Self-initiated expatriates (SIEs) are defined as employees who are not assigned to another country by an organisation but have instead chosen to move to another country to work and live on their own arrangement (Tharenou and Caulfield, 2010). SIEs are looking for greater exposure, good quality of life, financial sources and international experience. Moreover, SIEs are primarily those people who love travelling and willing to know more about different cultures and countries. Beside all, they are people fond of diversity and mostly have single marital status.

In addition, SIEs are very different from traditional expatriates or assigned expatriates. Assigned expatriates are those who are sent by their parent companies to the host country for a specific period of time in order to complete certain organisational goals but self-initiated expatriates are people who search employment themselves and are accountable for their expatriation and repatriation during international assignments. Above all, SIEs are advantageously precious human resources for companies and their employment rate has been increasing drastically in many countries due to the talent shortage and increasing demand for inter-culturally flexible employees with more differentiated skills sets (Deloitte, 2010).

We draw attention to the fact that the SIEs' literature, is growing, but seems to be developing without a clear basis. Companies in upward countries are keen to hire SIEs. New market, quick growth, international goal and managerial development appear to force the requirement for SIEs. The national capital of India as a metropolis has large number of SIEs belonging to different cultures and nations. Last but not the least there are many local companies which are considerably interested to hire SIEs and the future of SIEs in India in particular in Delhi NCR seems great.

\section{Literature review}

Several authors discussed SIEs well and have given a deep understanding of the concept (Doherty, 2013; McNulty and Brewster, 2017). Studies reveal that SIEs like to move to countries that have same culture, tradition and system (Doherty et al., 2010; Tharenou 
and Caulfield, 2010). SIEs are defined as individuals who are individually accountable for their career without the direct support of an organisation (Carr et al., 2005). Hence, individuals who take the decision to reside and have a job overseas are called SIEs.

SIEs expatriates have been called with different names in literature such as self-selecting expatriates (Richardson and McKenna, 2003), self-initiated movers (Thorn, 2009), self-designed apprenticeship (Arthur et al., 1999) and free travellers (Myers and Pringle, 2005). SIEs are people who decide to take up an international assignment overseas and they are not sent by anyone to work in the international marketplace (Harrison et al., 2004). Moreover, SIEs are basically those people who relocate to a country of their choice in order to find their desirable job or attempt to find some business opportunities in the overseas market. Some of the characteristics of SIEs can be listed as, first, SIEs are individuals who are mostly below 30 years old and love to work, travel and stay overseas. Second, the SIEs are individuals who are actively looking for employment overseas, or are not happy with their current employment. Third, even former organisational expatriates contribute to the community of SIEs in the overseas markets. Fourth, SIEs are mostly dual career couples, either of the partners find a job overseas and they decide to move as a family. Fifth, SIEs are commonly well qualified and experts who support international professional career and companies hire them to fill the shortage of qualified managerial employees in the market (Jokinen et al., 2008; Saxenian, 2005).

Literature review also revealed that SIEs have different motives while moving overseas such as having the craving to go abroad and see the world, to meet the career ambitions get away from existing situations (Doherty et al., 2011; Carr et al., 2005). Moreover, SIEs desire to enhance their life style and quality of living rather than shift for financial motives (Richardson and McKenna, 2003). SIEs are furthermore motivated to take up international assignments in order to find out about different cultural surroundings and establishing fresh global networks (Myers and Pringle, 2005). Development of cross-cultural understanding, career outlook, enthusiasm, connecting with new and different citizens are some other factors motivating SIEs to take international assignments in the overseas market (Tharenou, 2003). Last but not the least (Dickmann et al., 2008; Peltokorpi and Froese, 2009) mentioned that SIEs show better cultural adjustment, capability to acclimatise to the host country and assurance in their ability to reside and work overseas than organisational expatriates. Furthermore, SIEs have better understanding of the host country culture and hence their adoption during international assignment is easier (Sargent, 2003). SIEs also value and extremely welcome interpersonal relationships (Bozionelos, 2009). SIEs are globally positional workforce (Myers and Pringle, 2005). SIEs never change their citizenship despite of the fact that they have chances of getting citizenship of other country during overseas employment. They often change job and organisation but return to their home countries at the end of the day.

The results of SIEs expectancies and motivational goals study shows that SIEs who had greater confidence in their ability to live and work abroad were also more likely to move to pursuit performance goals. They also reported greater host adjustment and superior professional accomplishments, but not higher family achievements or success (Pinto et al., 2020). Further, a recent study conducted in China, showed that career 
adaptability was significantly related to performance and adjustment as well as to psychological availability. Those SIEs with higher career adaptability may have better performance and adjustment because they have greater resources to draw upon to cope with evolving work and cultural uncertainties and demands. Because SIEs with higher levels of career adaptability have more resources, they can devote more energy to effective performance and adjustment. But, being fully engaged at work may not greatly influence SIEs' adjustment because adjustment may be more dependent on other factors (e.g., spouse's adjustment, having an HCN as a mentor) (Jannesari and Sullivan, 2019a, 2019b).

\section{Research problem}

A growing movement of foreign nationals (SIEs) is settling in Delhi, National Capital Region (NCR). Given this, there is a need to understand their lived experiences as to identify the challenges and issues faced by them during their stay. And, also to study the motives that influence these SIEs to settle in this region as a basis for individual career development.

\section{Research objectives}

- To study the motives of SIEs to take up assignment in Delhi NCR.

- To identify the issues and challenges faced by SIEs during international assignment in Delhi NCR.

\section{Research methodology}

\subsection{Primary data}

This study has primarily based on the primary data which has been collected though a semi-structured interview technique. The semi-structured interview of the participants has been conducted in the face to face mode and the time spent was around 30-35 minutes. A total 19 questions were asked to the participant and their responses recorded.

\subsection{Secondary data}

Secondary data from different international journals, research thesis, online Wikis, books on SIEs and weblogs has been reviewed for better understanding of the concept in order to find out the research gap. The secondary data on relevant areas has been also reviewed carefully in order to support the primary data and findings. 


\subsection{Sampling technique}

A total of 30 participants were approached to take part in this study out which 25 SIEs accepted to be part of the study. The sample for this study was gathered using a combination of sampling methods, namely: judgmental and convenience sampling. In this regard, participants had to be SIEs who were accessible to the researchers because of time and budget constraints. Given the nature of the study, the researcher found convenience sampling technique affordable and a best way to select participants.

\subsection{Population of the study}

In India, Delhi NCR, is emerging as one of the favourite destinations of the SIEs to stay during an international assignment. This capital city has been a home to a large number of SIEs coming from different countries and having diverse backgrounds. Hence, the population of the study was chosen irrespective of the country of origin. The population of the study comprised of the nationalities from - the Netherlands, Spain, Belgium, France, UK, Sri Lanka, Vietnam, Myanmar, China, Indonesia, Russia, Mexico, Afghanistan, Thailand, and the USA.

\subsection{Stay duration of the respondents}

India provides different categories of visas to the foreign nationals as per the nature of their stay. These visa types include student visa, research visa, employment visa, business visa, medical visa, tourist visa. A SIE has to get employment visa or business visa, in order to be eligible to work in India. Indian visa, initially, is given for three months, which can be further extended up to five years. Foreigner Regional Registration Office (FRRO) of the concerned state/city is the department responsible for issuing and extension of visa. Foreign nationals have to apply for a fresh visa after the completion of five-years, in order to extend their stay in this country. Hence, the duration of participants interviewed for this study ranges from three months to five years (refer Table 1).

\subsection{Location of the study}

The capital of the country is generally a popular place among the foreigners. Hence, Delhi NCR is a known city among expatriates working in India. Being a capital city, Delhi offers luxurious lifestyle and a decent standard of living. The participants of this study were from Delhi NCR which includes cities like Noida, Gurugram, Ghaziabad, Okhla, South Extension, Greater Kailash, Safadarjung Enclave, Lajpat Nagar, etc.

\subsection{Research design}

It is an exploratory research based on primary data or first-hand data. The interpretive paradigm was adopted to understand the main purpose of the study. Guided by study objectives, semi-structured interviews were conducted of 25 SIEs residing in Delhi NCR. The overall research question guiding this study was: what factors (given the Delhi NCR context) influence SIEs to expatriate and the ensuing lived experience accompanying this decision? 
A total of 30 potential participants were approached and finally 25 participants took part in the study. These participants were from different countries and on average below 30 years old. Initially there were 25 questions which were selected for the interview but after careful filtering, 19 questions were asked during the interviews to each of the participant. The interviews were successfully conducted in one go on and recordings done on smart phone for analysis and verification. The participants found interviews very interesting, as most of them were invited to participate in the study either in a coffee shop or a restaurant of their choice.

The researchers have chosen questions from an established questionnaire and the questions were well structured and designed. Furthermore, they were concise, brief and reliable in order to achieve most relevant results. For the purpose of the analysis, the authors have used the narratives of the interviewees to identify a given keyword and then attached a meaning to this keyword as understood from the review of the literature on SIEs.

\section{$6 \quad$ Findings}

The demographic characteristics of the 25 participants and their pseudonyms (used to protect their identity) are illustrated in Table 1.

Out of the 25 respondents, the majority of the SIEs interviewed were young males and females in the age bracket of less than or equal to 30 years. The total number of male participants were $17(68 \%)$ and remaining $8(32 \%)$ were females. Majority of the respondents, around $72 \%$ wee single and the remaining $28 \%$ were either married or divorced. Given the nationality of the SIEs for this study, the respondents came from different parts of the world that included both developed countries such as USA, UK, and Russia, as well as developing countries such as Mexico and China. The average stay of these participants in Delhi NCR ranges from 2 years to 6 years.

\subsection{Motives of SIES}

SIEs have different motives while accepting international assignments and their expectations have been constantly on a rise. Some of the motives with their corresponding narratives from the interviews have been listed in Table 2. First motive is identified as the financial gains and financial rewards which keep SIEs motivated to look for international assignments. SIEs receive handsome pay-package compared to the local fellows. It is such that local companies and even multinational corporations pay comparatively better salary to the international staff than to the local employees. Financial rewards further keep SIEs motivated, not only to complete a given assignment but also to extend their stay. The findings corroborate with the previous studies conducted mostly in western countries that attribute a sense of adventure, monetary issues, family and partner considerations, life change and personal development as influencing factors amongst expatriates (Al Ariss and Syed, 2011; Howe-Walsh and Schyns, 2010; Selmer and Lauring, 2012). 
Table 1 Demographic profile of the participants

\begin{tabular}{|c|c|c|c|c|c|c|}
\hline S. no. & $\begin{array}{l}\text { Pseudo } \\
\text { name }\end{array}$ & Gender & $\begin{array}{l}\text { Marital } \\
\text { status }\end{array}$ & Nationality & Designation & $\begin{array}{c}\text { Years in } \\
\text { India }\end{array}$ \\
\hline 1 & Karan & Male & Single & USA & Manager & 6 years \\
\hline 2 & John & Male & Married & China & Teacher & 4 years \\
\hline 3 & Caren & Male & Single & China & Manager & 3 years \\
\hline 4 & Sim & Male & Single & Romania & Journalist & 5 years \\
\hline 5 & Lahri & Male & Single & Sri Lanka & Manager & 2 years \\
\hline 6 & Neil & Male & Single & Myanmar & Interpreter & 1 year \\
\hline 7 & Subbu & Male & Married & Vietnam & Interpreter & 3 years \\
\hline 8 & Aby & Male & Single & Indonesia & Teacher & 2 years \\
\hline 9 & Mary & Male & Married & Russia & Teacher & 3 years \\
\hline 10 & Venky & Male & Single & Myanmar & Interpreter & 1 year \\
\hline 11 & Johnny & Male & Single & Netherlands & Manager & 1 year \\
\hline 12 & Prince & Male & Single & Spain & Teacher & 1 year \\
\hline 13 & Tom & Male & Divorced & Russia & Teacher & 9 years \\
\hline 14 & Moor & Male & Married & Afghanistan & Translator & 9 years \\
\hline 15 & Tony & Male & Single & Turkmenistan & Translator & 7 years \\
\hline 16 & Luke & Male & Single & France & Manager & 2 years \\
\hline 17 & Ravy & Male & Single & UK & Manager & 2 years \\
\hline 18 & Sue & Female & Single & Spain & Teacher & 2 years \\
\hline 19 & Heena & Female & Single & Iran & Exporter & 9 years \\
\hline 20 & Nancy & Female & Single & Mexico & Teacher & 8 years \\
\hline 21 & Sam & Female & Married & Afghanistan & Translator & 2 years \\
\hline 22 & Betty & Female & Married & France & Teacher & 2 years \\
\hline 23 & Vinnie & Female & Single & Thailand & Teacher & 6 years \\
\hline 24 & Jeny & Female & Single & Belgium & Teacher & 8 years \\
\hline 25 & Princy & Female & Single & Sri Lanka & Manager & 5 years \\
\hline
\end{tabular}

Second, SIEs consider career advancement and exposure as one of the biggest motivational factors for accepting international assignments. International assignment gives them the opportunity to advance their career and create a wonderful career history. It further adds significant advancement in terms of skills gained and lessons learned. Career advancement also helps SIEs to grab best available opportunities and it enables them to work with the best organisations.

Cross-cultural experience is third major motivator which influences SIEs to take up international assignments. Cultural diversity and differences always attract people and it is one of the biggest factors which enrich SIEs in terms of values, traditions and tolerance. 
Table 2 Motives of SIEs

\begin{tabular}{lll}
\hline Motivating factor & \multicolumn{1}{c}{ Meaning } & \multicolumn{1}{c}{ Illustrating quotes } \\
\hline Financial gains & $\begin{array}{l}\text { SIEs are able to earn more and } \\
\text { save more. }\end{array}$ & $\begin{array}{l}\text { "I am able to save more money than } \\
\text { what I used to in my home country. } \\
\text { Jobs are well paid and cost of living is } \\
\text { affordable." }\end{array}$ \\
$\begin{array}{l}\text { Career } \\
\text { advancement and } \\
\text { exposure }\end{array}$ & $\begin{array}{l}\text { SIEs move to different country to } \\
\text { augment their career } \\
\text { development. It enables them to } \\
\text { work with some of the best } \\
\text { organisations. }\end{array}$ & $\begin{array}{l}\text { metropolitan city provides good job } \\
\text { prospects for me and my spouse." }\end{array}$ \\
$\begin{array}{l}\text { Cross-cultural } \\
\text { experiences and } \\
\text { quality of life }\end{array}$ & $\begin{array}{l}\text { SIEs look for enriching their } \\
\text { cultural experiences and look for } \\
\text { a better quality of life then what } \\
\text { their home country has to offer. }\end{array}$ & $\begin{array}{l}\text { "I believe south Delhi is one of the } \\
\text { best places in Delhi a person should } \\
\text { choose to live for as long as he wants } \\
\text { because this is the area where a lot of } \\
\text { people are educated and most settled." }\end{array}$ \\
\hline
\end{tabular}

Job challenge is the fourth factor motivating SIEs to take up international assignment. SIEs believe that changing job frequently make them expert and qualified enough for future employment. Personal growth has been placed at the fifth position, in terms of significant factors motivating SIEs to take up international assignments. Family reasons, and location were not motivating enough for expatriates to take-up assignment in Delhi NCR region.

Figure 1 Motives of SIEs to stay in Delhi NCR

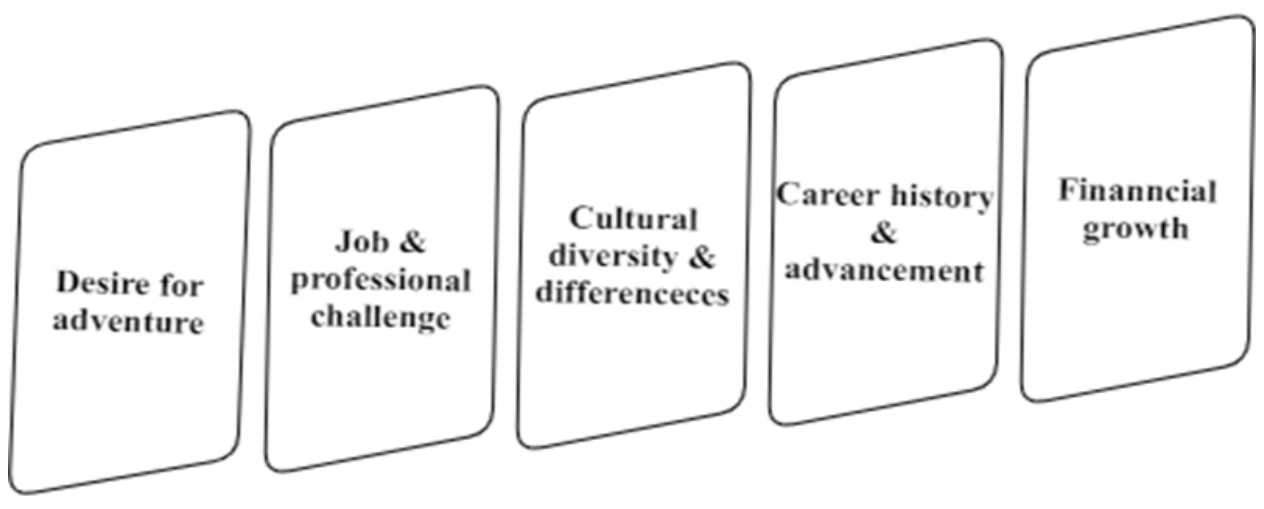

\subsection{Issues and challenges of SIEs}

Self-initiated expatriates face certain issues and challenges while moving to India. Moreover, their challenges and issues are considered to be the main hindrance towards their personal and professional life. In addition, self-initiated expatriates experience these issues and challenges almost irrespective of their country of origin and the type of employment or industry as evident from the narratives listed in Table 3.

All the participants in the study faced one or many of the issues and challenges during their stay in Delhi NCR as classified in Figure 2. 
Table 3 Issues and challenges of SIEs

\begin{tabular}{|c|c|c|}
\hline Issues/challenges & Meaning & Illustrating quotes \\
\hline $\begin{array}{l}\text { Legal } \\
\text { documentation } \\
\text { process as a } \\
\text { challenge }\end{array}$ & $\begin{array}{l}\text { There is a lack of clarity } \\
\text { and a set process in terms } \\
\text { of getting the formalities } \\
\text { completed related to the } \\
\text { documentation and legal } \\
\text { process. }\end{array}$ & $\begin{array}{l}\text { "The process of getting visa is difficult and } \\
\text { when you come here you won't get any } \\
\text { facility people will not guide you. You have } \\
\text { to do everything yourself so if you don't } \\
\text { have any guide you will be like lost and you } \\
\text { will be lost everything that you came with } \\
\text { like your money, etc." }\end{array}$ \\
\hline $\begin{array}{l}\text { Transportation } \\
\text { and commuting as } \\
\text { a challenge }\end{array}$ & $\begin{array}{l}\text { Public transportation is } \\
\text { crowed, dirty and at times } \\
\text { unsafe. People tend to } \\
\text { disobey rules and private } \\
\text { transportation is } \\
\text { expensive. }\end{array}$ & $\begin{array}{l}\text { "The transport is very good in my country I } \\
\text { cannot compare but in Delhi the metro is } \\
\text { very okay but transport between province } \\
\text { and state is very bad. If you have money you } \\
\text { can pay for an expensive class and there is no } \\
\text { space and too much crowds and there are } \\
\text { insects." }\end{array}$ \\
\hline $\begin{array}{l}\text { Housing/ } \\
\text { accommodation as } \\
\text { a challenge }\end{array}$ & $\begin{array}{l}\text { Old buildings without } \\
\text { proper ventilation and } \\
\text { water/drainage system } \\
\text { rents are high and policy } \\
\text { of discrimination. }\end{array}$ & $\begin{array}{l}\text { "I think pretty much everything related to } \\
\text { housing is crumbling like there is no proper } \\
\text { water and electricity system and construction } \\
\text { here is not newer than ten years and it is also } \\
\text { not clean." }\end{array}$ \\
\hline $\begin{array}{l}\text { Cultural barriers } \\
\text { and adjustment } \\
\text { aspects }\end{array}$ & $\begin{array}{l}\text { Locals tend to cheat/ } \\
\text { overcharge foreign } \\
\text { nationals. Unhealthy } \\
\text { mindset towards female } \\
\text { SIES. }\end{array}$ & $\begin{array}{l}\text { "I don't like people here. There are very } \\
\text { snaky and they are very conniving. They like } \\
\text { to steal money from foreigners they will try } \\
\text { to take advantage of you and they will } \\
\text { overcharge you." }\end{array}$ \\
\hline
\end{tabular}

Figure 2 Issues and challenges of SIEs

\begin{tabular}{|c|}
\hline Quality of life and housing \\
\hline Safety and security \\
\hline Legal and documents related challenges \\
\hline Health care facilities \\
\hline Transporation and commuting issues \\
\hline Cultural barriers and adjusment concerns \\
\hline Envrionmental concerns \\
\hline
\end{tabular}

\subsubsection{Quality of life and housing}

Accommodation is a major concern that has been reported by most of the SIEs during the interviews. Most of the SIEs commented on the poor maintenance and upkeep of the residential buildings. Buildings also have cockroaches, bugs and insects. In addition, some of the buildings do not have proper water or power back-up system. Lack of proper 
ventilation, poor elevator facilities and no provision for centralised heating are some of the other issues in terms of housing which have been reported by the SIEs. They also mentioned that housing is very expensive in terms of rent and utility bills.

Expatriates generally have to pay more for rent, water and electricity bills and at times, have to part with higher maintenance charges. Expatriates also believe that many landlords are opportunist as they increase rent unnecessarily and do not follow the terms and conditions mentioned in the rent agreement. SIEs interviewed are also of the opinion that some of the landlords are very annoying as they interfere in tenant's personal life. There have been few instances of a hidden camera being installed by the landlords to keep a watch on the tenant. but most of the SIEs are of the view that the cost of living in terms of essential commodities like food items, clothing and shopping is affordable and decent.

Figure 3 SIEs housing issues and challenges

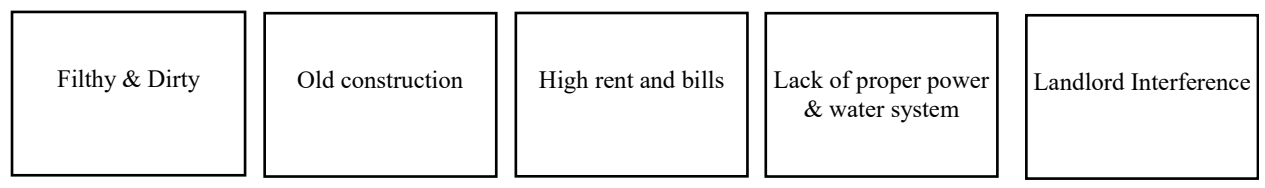

\subsubsection{Safety and security}

Safety and security are directly found to be linked to the choice of place to live, in case of SIEs. For instance, outskirts of Delhi are not considered to be safe after 10 PM. Posh areas of Delhi, given their high-security measures, are on the top list when it comes to making a selection of a place to live. Safety and security in particular during night is a major issue for SIEs, as they believe going alone in night is risky in Delhi NCR. And the risk increases manifolds, in case of females. Female SIEs also mentioned that they do not feel safe around a crowd of Indian males, as they misbehave, comment and stare. South Delhi, especially areas such as Lajpat Nagar, Chanakyapuri, and South Extension are considered to be safe by SIEs as compared to west, east or north Delhi. Robbery and snatching are a common instance while travelling by bus or using a public transport. Over charge, cheating and scams are some other issues which expatriates are bothered about while making a purchase or planning something to do.

Figure 4 SIEs safety and security issues

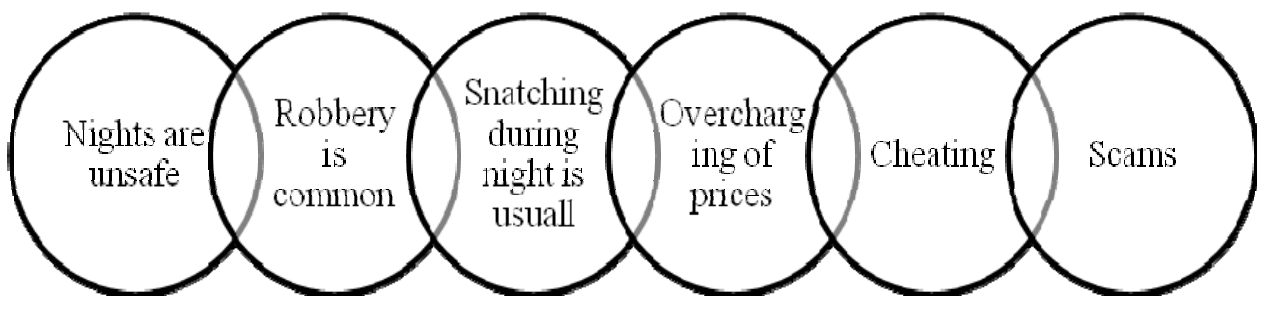

\subsubsection{Legal and documentation process as a challenge}

The legal and documentation process can either be smooth or a cause of anguish. Sometimes it all depends on the state of mind of the official handling the case. These 
officials can either make things very easy or it can turn out to be an exhausting experience for SIEs. The process also depends on the country of origin of SIEs, for example, if the SIE is from USA, then the process is comparatively smoother than the other countries. The legal and documentation challenges do not end on obtaining a valid visa, instead, there are lot of formalities which need to be completed on arrival too. First, registration with foreign regional registration office which is generally very time consuming and complicated. Second, seeking local police verification is not an easy task. Third, applying for PAN card and bank account for conducting financial transactions is a hassle and time consuming. In SIEs' opinion, coming to India is easy, but getting through application processing and documentation is a daunting task.

Figure 5 SIEs legal and document related issues (see online version for colours)

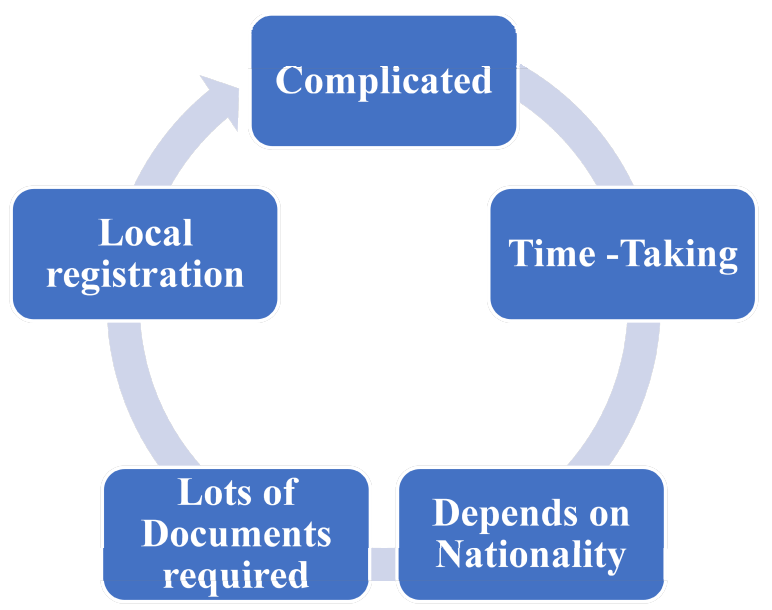

\subsubsection{Healthcare facilities}

India is considered to be one of the best healthcare destinations in the world. And Delhi NCR has the some of the largest multispecialty hospitals of the country, offering the best medical services. Unfortunately, in the absence of proper monitoring system, SIEs, feel that these hospitals over charge. From the interviews conducted, most of the SIEs felt that there is $25 \%$ difference between the treatment cost of a local and an expert. The doctors are cooperative but many of them are found to be giving unnecessary tests when it comes to foreign patients. Expatriates also believe that private hospitals are good but at the same time very expensive. SIEs did not find the government hospitals suitable for treatment, as they are generally very crowded and proper attention is missing.

Figure 6 Healthcare facilities

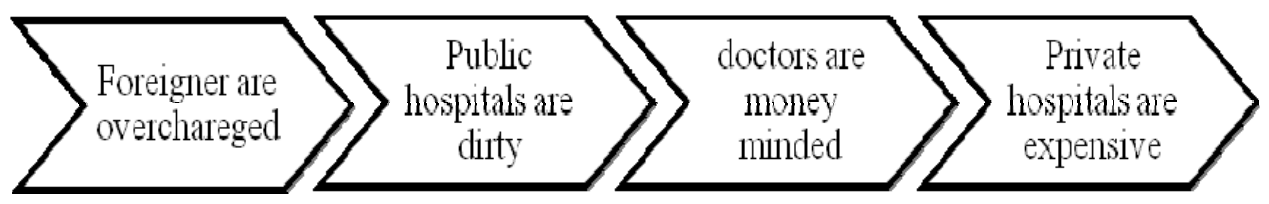




\subsubsection{Transportation and commuting issues}

Most of the SIEs interviewed are of the opinion that public transport, especially, bus is not advisable as an ideal means of transport. Public buses are overcrowded, and sometimes dirty and unsafe. The only public transport which is recommended by most of the SIEs is metro. But it is often found to packed to its capacity, and people usually do not follow rules while boarding. Buying a private car or vehicle is of no use, given the heavy traffic on roads which lead to traffic jams and congestion. Furthermore, parking space is another issue when buying a car or a vehicle. It is very difficult to have comfortable and luxury transportation facility as one has to walk down the lane/street to board a private transportation such as Uber or Ola. Last, but not the least, changing different means of transportation in order to reach a destination is also very exasperating and time consuming.

Figure 7 Transportation and commuting issues

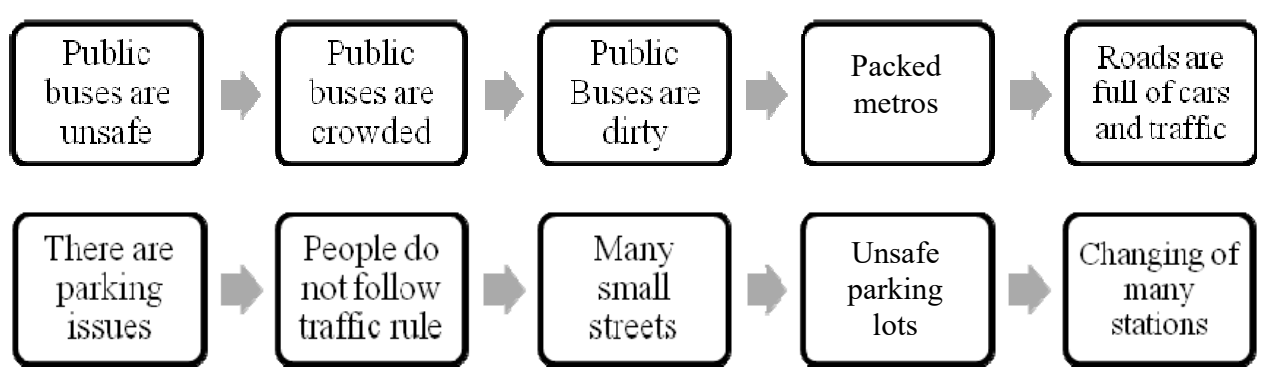

\subsubsection{Cultural barriers and adjustment aspects}

SIEs experience cultural shock on their arrival which they eventually overcome in due course of time. Inability to speak local language is one of the biggest cultural barriers that SIEs experience, in order to manage day today affairs such as daily shopping and local commute. Food is another issue which popped often, in due course of the interview. Indian food is considered to be too spicy to suit their taste buds. India being a Hindu country, restaurants offering non-vegetarian food (beef and pork) are less in numbers. In addition, food which is affordable and accessible, is generally found to be oily and unhygienic. Thinking pattern towards female SIEs is also found to be demeaning. Staring and misbehaving are quite frequent and common in public and crowded places.

Figure 8 Cultural barriers and adjustment aspects

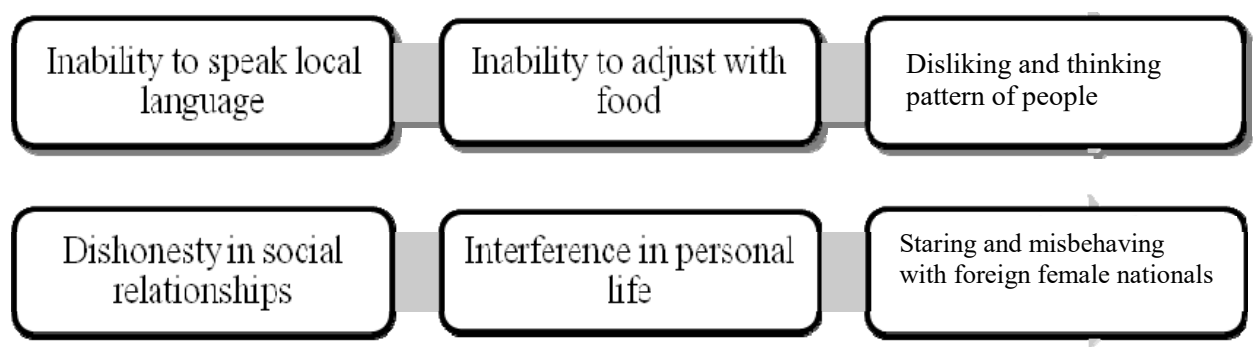


Further, it has come up during the interviews that the local people perceive that expatriates are rich people and they can be cheated or over-charged. Dishonesty in terms of social conducts and work is so much that it disturbs professional and personal life during assignment. Irresponsibility towards law and order in particular in terms of traffic and public transport is also widespread. In the course of the interviews of SIEs, it has also surfaced that SIEs do not have full independence to express/ discuss politics and religious issues.

\subsubsection{Environmental issues and concerns}

Harsh weather, especially the summer season, is found to be of uncomfortable for SIEs who were interviewed. The weather in Delhi NCR is of concern to SIEs so much that, sometimes, it compels them to leave their assignments. Hygiene is also a major issue during their stay in Delhi NCR. Unfortunately, though being a capital, Delhi NCR is not an ideal example of germ-free city to reside and work. Clean drinking water is really precious in Delhi NCR, and at times, it becomes difficult to procure. Even the water which is being sold in the market is not considered to be truly pure, unless of a good brand.

In addition, during rains, there is a severe problem of water clogging and overflowing of drains. Power lines on the road and streets are also a matter of concern, as at places, these are unorganised and unsafe. The city comprises of lanes and by-lanes, and one may feel lost if unfamiliar with the area. SIEs also believe that Delhi NCR is not an ultimate place to live, in terms of the air and noise pollution. Especially in winters, air pollution is of major concern, particularly for children.

Figure 9 Environmental issues and concerns

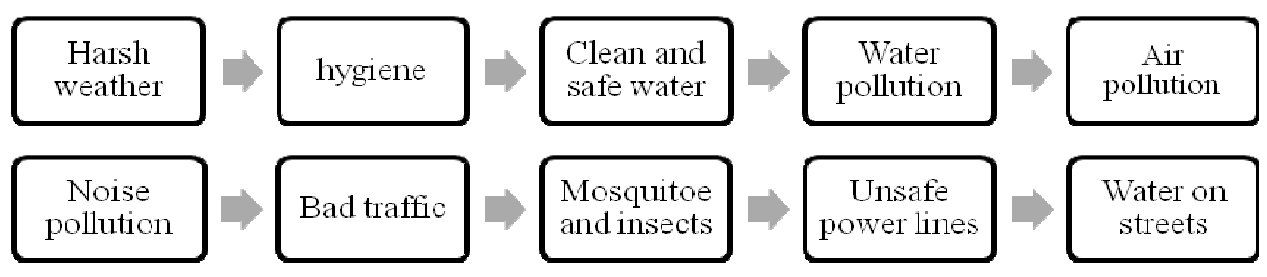

\section{Discussion}

The findings of this study are in tandem with the existing literature on factors influencing SIEs experiences. According the findings of the current research in many ways, the main finding state that the participants felt the need to experience new lives in other countries and develop their careers, and thus were motivated to expatriate. New life experiences and career development have been noted as some of the major factors that influence expatriation (Andresen et al., 2012; Froese, 2012; Mostert, 2014; Van den Bergh and Plessis, 2012). Research to date indicates that while career is not a central concern to SIEs, as they are engaged in gainful employment and have varying career outcomes from the experience (Doherty and Dickmann, 2012). But career, perhaps is an important element of the SIE experience at the individual level (Doherty et al., 2011; Thorn, 2009). 
Career from an organisational level perspective is also important, in particular to the engagement and performance outcomes of SIE (Thorn and Inkson, 2012).

The findings also indicate that the quality of life and housing, safety and security, legal and documentation, healthcare challenges, transportation and commuting challenges, environmental concerns and cultural barriers and adjustments have come up as major issues and challenges faced by SIEs in Delhi NCR. As evident from the findings, the utmost issue for the participants was accommodation and in line with the previous literature (Froese, 2012). As in previous studies, lack of housing led to family separation which eventually led to loneliness (Mostert, 2014). Furthermore, the inability of the family members to adapt to the host country's culture and language led to family separation (Van den Bergh and Plessis, 2012) also has also turned out to be an issue in the present study.

Furthermore, as in previous studies, most participants felt like outsiders because of culture and language differences which made it difficult for them to blend in with the community (Froese, 2012; Richardson and McKenna, 2002). In particular, participants were found to be unsatisfied with the hygiene, safety and security, thinking pattern, housing issues, overcharging, visa processing and traffic related matters.

\section{Ethical considerations}

During the course of study all measures have been taken to make sure that study should be ethical and morally appropriate. Every participant was explained the purpose of the study and regarding potential advantages and disadvantages associated with the study. In addition, a written consent was taken from the participants.

\section{Practical implications}

There is growing trend for SIEs in India, especially in Delhi NCR region. Though, Indians are already well qualified and smart enough to perform any type of job, there is still a need for well-qualified talent (SIEs) to plug the talent crunch. Moreover, SIEs are viewed as less expensive labour but at the same time equally skilled and capable when compared with traditional expatriates. SIEs can be hired, instead of organisational expatriates as they are more successful and adjustable in terms of doing an overseas job. Although the achievements in the area of research and studies on expatriation has proven that expatriates significantly contribute to the success of a corporation in foreign markets, the expatriation management is still a weak point in many international organisations, in the field of human resource management. Particularly, in the area of repatriation and adaptation to foreign culture.

Organisations should perceive SIEs as valuable human resources and frame their IHRM policies taking into consideration this new set of work force. Attracting and retaining skilled workers is an important issue with most of the multi-national corporations and they can reap the workforce dividend by including SIEs. Furthermore, organisations should also accept that skilled SIEs play an important role in the development of local employees through development of transferable skills or knowledge-sharing. The organisations should formulate such IHRM policies and practices that assist SIEs to attain housing/accommodation easily during an international 
assignment, as it was illustrated as one of the major challenges faced by SIEs. Additionally, organisations should create social networks for the SIEs and their families to help them make a smooth transition to the host country's culture and language. Linking the implications with the literature, it has been found in a recent SIEs study in Japan, that there is a gap between Japanese firms' expectations and international labour expectations (SIEs); the former expects the latter to stay for the long-term, while the latter prefers variety of job experiences in order to quickly develop skills. Under the traditional Japanese HR system, both sides seem to suffer if they work together for long (Yorozu, 2020). Thus, such differences can be taken care of with the help of a well-designed training program covering varied facets of expatriation. Further, a well-drawn cross-cultural training program can also be rendered by the HR of organisations, which hire SIEs, to sensitise them about the various cultural aspects.

\section{Limitations of the study and future research}

There is a need for detailed research on SIEs as the present study is limited to Delhi NCR only. Being a qualitative study, and given the small sample size, the findings of the study cannot be generalised. There is a need to conduct detailed empirical studies at the pan India level. Moreover, the findings will be different when studying SIEs according to their country of origin and the type of industry they work in. Researchers and scholars can take up other aspects such as country of origin, profession, age, gender for further research in this area.

\section{Conclusions}

The process for SIE is different from assigned expatriate in many ways. SIEs are active job seekers and they usually work with different companies. SIEs generally do not attend any form of training while moving overseas. Furthermore, self-initiated expatriation is considered as an opportunity and change among people and it is not a duty any more. In addition, our finding shows SIEs despite of having many challenges consider Delhi NCR a favourable destination to work, and self-initiated expatriation is considerably growing, particularly, in Indian context. Many Indian origin companies and even MNCs hire SIEs in order to fill the shortage of talented workforce. Moreover, many SIEs are hired in Indian companies as part of their marketing strategies. SIEs, mostly work in sectors such as education, export and import, and consultancy. The failure rate of self-initiated expatriation is comparatively very low as they are mostly single, young and well qualified. Moreover, they love to travel and like challenges and adventure. Hiring of SIEs is not much expensive as the hiring organisation is least responsible towards their personal and professional life during the assignment, except for their legal process and documentation. Self-motivation, personal commitment, flexibility, individual ability to deal with uncertainty are some factors contributing to a successful self-initiated expatriation. Management support, colleagues support culture barriers are not rated as the top reasons for an effective performance while working overseas. During the course of study, some of the failure stories have also come in limelight which can be attributed to lack of international experience, social skills, technical skills, lack of career growth. Other reasons such as unsafe environment, insufficient language skills, expatriate's 
personal emotional maturity, lack of cultural empathy and partner's inability to adjust were found to be least impactful. South Delhi is the best place to dwell and areas like Greater Noida are reported unsafe during night. Legal and documentation process is very slow and found to be time consuming. Further applying for an employment visa is complex, and not that easy to obtain. Hygienic and clean public places, transportation and housing are a matter of great concern for SIEs. Healthcare system is good but expensive and cost of living is moderate. Robbery and cheating were some of the major issues that have emerged in our findings in our findings. Public transport is affordable but bustling and considered to be unsafe. Flexibility, diversity, weather, street food, festivals, and local markets are some of the reasons which make Delhi NCR as one of the favourite cities of SIEs.

\section{Acknowledgements}

The authors are thankful to the participants for their participation in the study. And, are also grateful for support received from their friends and families during the course of study.

\section{References}

Al Ariss, A. and Syed, J. (2011) 'Capital mobilization of skilled migrants: a relational perspective', British Journal of Management, Vol. 22, No. 2, pp.286-304 [online] https://doi.org/10.1111/ j.1467-8551.2010. 00734.x.

Andresen, M., Al Ariss, A. and Walther, M. (2012) Self-Initiated Expatriation: Individual, Organisational and National Perspective, Routledge, New York.

Arthur, M., Inkson, K. and Pringle, J. (1999) The New Careers: Individual Action and Economic Change, Sage.

Bozionelos, N. (2009) 'Expatriation outside the boundaries of the multinational corporation: a study with expatriate nurses in Saudi Arabia', Human Resource Management, Vol. 48, No. 1, pp.111-134, The School of Business Administration, The University of Michigan and The Society of Human Resources Management.

Carr, S.C., Inkson, K. and Thorn, K. (2005) 'From global careers to talent flow: reinterpreting 'brain drain', Journal of World Business, Vol. 40, No. 4, pp.386-398, ISSN 1090-9516, https://doi.org/10.1016/j.jwb.2005.08.006.

Deloitte (2010) Talent Edge 2020: Blueprints for the New Normal [online] http://www.deloitte.com/view/en_US/us/Services/additional-services/talent-human-capital$\mathrm{hr} /$ Talent-Library/talent-edge-2020/index.html.

Dickmann, M., Doherty, N., Mills, T. and Brewster, C. (2008) 'Why do they go? Individual and corporate perspectives on the factors influencing the decision to accept an international assignment', The International Journal of Human Resource Management, Vol. 19, No. 4, pp.731-751.

Doherty, N. (2013) 'Understanding the self-initiated expatriate: a review and directions for future research', International Journal of Management Reviews, Vol. 15, No. 4, pp.447-469.

Doherty, N. and Dickmann, M. (2012) 'Self-initiated expatriation: drivers, employment experience and career outcomes', in Andresen, M., Al Ariss, A., Walther, M. and Wolff, K. (Eds.): Self-Initiated Expatriation: Mastering the Dynamics, pp.122-142, Routledge, London.

Doherty, N., Dickmann, M. and Mills, T. (2010) 'Mobility attitudes and behaviors among young Europeans', Career Development International, Vol. 15, No. 4, pp.378-400. 
Doherty, N., Dickmann, M. and Mills, T. (2011) 'Exploring the motives of company-backed and self-initiated expatriates', The International Journal of Human Resource Management, Vol. 22, No. 3, pp.595-611.

Froese, F.J. (2012) 'Motivation and adjustment of self-initiated expatriates: the case of expatriate academics in South Korea', The International Journal of Human Resource Management, Vol. 23, pp.1095-1112 [online] https://doi.org/10.1080/09585192.2011. 561220.

Harrison, D.A., Shaffer, M.A. and Bhaskar-Shrinivas, P. (2004) 'Going places: roads more and less travelled in research on expatriate experiences', Research in Personnel and Human Resource Management, Vol. 23, pp.199-247.

Howe-Walsh, L. and Schyns, B. (2010) 'Self-initiated expatriation: implications for HRM', International Journal of Human Resources Management, Vol. 21, pp.260-273 [online] https://doi.org/10.1080/09585190903509571.

Jannesari, M. and Sullivan, S.E. (2019a) 'Career adaptability and the success of self-initiated expatriates in China', Career Development International, DOI: 10.1108/CDI-02-2019-0038.

Jannesari, M. and Sullivan, S.E. (2019b) 'Career adaptability and success of SIEs career adaptability and the success of self-initiated expatriates in China' [online] https://www. researchgate.net/publication/334749665 Career Adaptability and Success of SIEs Career Adaptability_and_the_Success_of_Self-Initiated_Expatriates_in_China (accessed $1 \overline{1}$ October 2020).

Jokinen, T., Brewster, C. and Suutari, V. (2008) 'Career capital during international work experience', International Journal of Human Resource Management, Vol. 19, pp.979-998.

McNulty, Y. and Brewster, C. (2017) 'Theorizing the meaning(s) of 'expatriate': establishing boundary conditions for business expatriates', The International Journal of Human Resource Management, Vol. 28, No. 1, pp.27-61.

Mostert, E. (2014) Exploring Push and Pull Factors Experienced by South African Self-Initiated Expatriates, Unpublished Master's dissertation, Human Resources Department, University of Pretoria, Pretoria.

Myers, B. and Pringle, J.K. (2005) 'Self-initiated foreign experience as accelerated development: influences of gender', Journal of World Business, Vol. 40, No. 4, pp.421-431.

Peltokorpi, V. and Froese, F.J. (2009) 'Organizational expatriates and self-initiated expatriates: who adjusts better to work and life in Japan?', The International Journal of Human Resource Management, Vol. 20, No. 5, pp.1096-1112.

Pinto, L.H., Cabral-Cardoso, C. and Werther Jr., W.B. (2020) 'Expectancies and motivational goals of self-initiated expatriates as predictors of subjective assignment achievements and success', Management Research Review, Vol. 43, No. 4, pp.427-445 [online] https://doi.org/ 10.1108/MRR-07-2019-0319.

Richardson, J. and McKenna, S. (2002) 'Leaving and experiencing: why academics expatriate and how they experience expatriation', Career Development International, Vol. 7, No. 2, pp.57-68 [online] https://doi.org/10.1108/13620430210421614.

Sargent, T. (2003) Boundaryless Careers in the Age of Globalization: Cross-cultural Adjustment of Westerners in Japan in Terms of Motivation to Initiate Sojourn.

Saxenian, A. (2005) 'From brain drain to brain circulation: transnational communities and regional upgrading in india and China', Studies in Comparative International Development (SCID), Vol. 40, No. 2, pp.35-61.

Selmer, J. and Lauring, J. (2012) 'Reasons to expatriate and work outcomes of self-initiated expatriates', Personnel Review, Vol. 41, pp.665-684 [online] https://doi.org/10.1108/ 00483481211249166.

Tharenou, P. (2003) 'The initial development of receptivity to working abroad: self-initiated international work opportunities in young graduate employees', Journal of Occupational and Organizational Psychology, Vol. 76, pp.489-515. 
Tharenou, P. and Caulfield, N. (2010) 'Will I stay or will I go? Explaining repatriation by self-initiated expatriates', The Academy of Management Journal, Vol. 53, No. 5, pp.1009-1028 [online] http://www.jstor.org/stable/20788806 (accessed 5 February 2021).

Tharenou, P. and Tharenou, P. (2009) 'Self-initiated international careers', Maintaining Focus, Energy, and Options Over the Career, p.197.

Thorn, K. (2009) 'The relative importance of motives for international self-initiated mobility', Career Development International, Vol. 14, No. 5, pp.441-464, https://oi.org/10.1108/ 13620430910989843

Thorn, K. and Inkson, K. (2012) 'Self-initiated expatriation and talent flow', in Andresen, M., Al Ariss, A., Walther, M. and Wolff, K. (Eds): Self-Initiated Expatriation: Individual, Organizational and National Perspectives, pp.75-89, Routledge, London.

Van den Bergh, R. and Plessis, D. (2012) 'Highly skilled migrant women: a career development framework', Journal of Management Development, Vol. 31, No. 2, pp.142-158 [online] https://doi.org/10.1108/02621711211199485.

Yorozu, C. (2020) 'How do self-initiated expatriates fit into the Japanese traditional HR system? A call for institutional change to achieve mutual understanding', Journal of Global Mobility [online] https://doi.org/10.1108/JGM-03-2020-0018. 